\title{
PENGEMBANGAN LEMBAR KERJA ANAK DENGAN MENGGUNAKAN PENDEKATAN KONSTRUKTIVISTIK UNTUK MENINGKATKAN KEMAMPUAN SAINS ANAK USIA DINI
}

\author{
Hardiyanti Pratiwi*) \\ diyankonayuki@gmail.com \\ Mustaji**) \\ mustaji_2005@yahoo.com
}

\begin{abstract}
Abstrak
Penelitian ini bertujuan untuk meningkatkan kemampuan sains anak melalui pengembangan produk berupa Lembar Kerja Anak (LKA) dengan menggunakan pendekatan konstruktivistik. Pengembangan ini menggunakan model Recursive, Reflective, Design and Development (R2D2) dengan tiga tahapan yaitu define focus, design and development focus, dan desimination focus. Instrumen pengumpulan data menggunakan teknik wawancara, observasi, dan pemberian angket. Data dianalisis secara deskriptif dan statistik dengan menghitung rata-rata dan persentase. Hasil uji coba produk menunjukkan bahwa: (1) produk yang dikembangkan sudah sesuai dan layak untuk digunakan. (2) Hasil observasi kemampuan sains pada aspek keterampilan mengamati diperoleh rata-rata nilai 95,75. Pada keterampilan mengklasifikasi diperoleh rata-rata nilai 100. Pada sikap tanggungjawab diperoleh rata-rata nilai 92,91. Pada hasil wawancara pada pemahaman konsep diperoleh rata-rata nilai 100. Data tersebut menunjukkan bahwa kemampuan sains anak-anak yang diberi perlakuan dengan produk yang dikembangkan dapat meningkat. Mereka mencapai skor yang melebihi standar, yaitu 2 bintang dengan nilai 66. Dengan kata lain, LKA dengan menggunakan pendekatan konstruktivistik yang dikembangkan bermanfaat dalam meningkatkan kemampuan sains anak.
\end{abstract}

Kata Kunci: Lembar Kerja Anak, Pendekatan Konstruktivistik, Kemampuan Sains.

\section{Abstract}

This research aims to develop worksheet for children $(L K A)$ by using Constructivist approach to enhance the younger children's science ability. The product was developed using Recursive, Reflective, Design and Development (R2D2) model with three stages are define focus, design and development focus, desimination focus. It used interview, observation, and questionnaires as instruments for data collection. The data, then, were analyzed descriptively and statistically by computing the mean and the percentage. The result of try out revealed that: (1) based on the expert of subject's validation, the developed product was appropriate.. (2) the result of observation in the field-testing stage showed that the younger children got mean 95,75 for their ability to observe, 100 for the ability to classify, 92,91 for their responsibility, and 100 for their understanding on the concepts of science.Those data revealed that the younger children who treated using the developed product were able to boost their science ability since they could achieve scores exceeding the standard, which are 2 stars. In other words, the Worksheet for Children $(L K A)$ by using Constructivist approach is helpful to improve the younger children's science ability

Keywords: Worksheet for Children, Constructivist Approach, Science Ability.

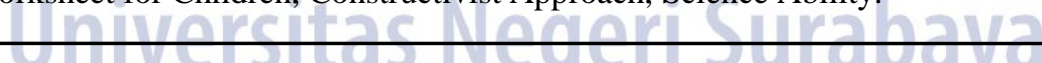

*) Mahasiswa Pascasarjana Unesa, Prodi Pendidikan Dasar Konsentrasi PAUD

**) Dosen Pembimbing I

\section{PENDAHULUAN}

Sains dalam Kamus Besar Bahasa Indonesia (Depdiknas, 2008: 1202) memiliki definisi sebagai pengetahuan sistematis yang diperoleh dari suatu observasi, penelitian, dan uji coba yang mengarah pada penentuan sifat dasar atau prinsip sesuatu yang sedang diselidiki, dipelajari dan sebagainya. Sains diajarkan kepada anak pada semua jenjang pendidikan hingga tingkat menengah atas, tanpa terkecuali pada jenjang Pendidikan Anak Usia Dini (PAUD).
Pada jenjang PAUD, sains merupakan bagian dari aspek pengembangan kognitif. Sains merupakan bidang ilmu yang sangat menarik untuk anak usia TK, karena pada jenjang TK pengenalan konsep sains mencakup halhal yang ada di sekeliling anak seperti hewan, tumbuhan, air, udara, bunyi, tanah, api, gejala sebab akibat, perubahan siang dan malam, dan lain-lain.

Konsep-konsep tersebut jika dikenalkan dengan pendekatan yang tepat akan sangat berarti bagi anak. Pada dasarnya pengenalan konsep sains pada anak TK 
untuk memenuhi rasa ingin tahu anak yang sangat tinggi. Selain itu, pengenalan konsep sains juga memenuhi kebutuhan anak sebagai penjelajah sejati yang suka mengeksplor sekelilingnya. Jika kebutuhan itu tersalurkan dengan tepat tentu akan berpengaruh positif terhadap aspek perkembangan kognitif khususnya dan aspek perkembangan lainnya secara umum.

Menurut Eshach \& Fried (dalam Trundle, 2005: 1), sains untuk anak usia dini sangat penting dalam mengembangkan beberapa aspek perkembangan anak, para peneliti menyarankan bahwa sains hendaknya dimulai pada awal tahap pendidikan. Mengajarkan sains pada anak usia dini bertujuan agar anak memiliki kecenderungan untuk menikmati kegiatan pengamatan dan memikirkan tentang alam. Anak termotivasi dalam mengeksplor dunia atau lingkungan di sekeliling anak. Pengalaman pembelajaran sains bagi anak akan membantu anak memahami dunia nya, mengumpulkan dan mengorganisir informasi, menerapkan dan menguji ide-ide serta mengembangkan sikap sikap positif terhadap sains.

Nugraha (2005: 1) juga mengemukakan bahwa kesadaran pentingnya pembekalan sains pada anak akan semakin tinggi apabila menyadari bahwa hidup dalam dunia yang dinamis, berkembang dan berubah secara terus menerus bahkan makin menuju masa depan, semakin kompleks ruang lingkupnya, dan tentunya akan semakin memerlukan sains.

Menurut Ashbrook (dalam Yulianti, 2010: 18) jika ingin anak-anaka mempunyai kinerja yang baik di sekolah lanjutan, maka anak usia dini (Taman Kanakkanak khususnya) hendaknya dibiasakan bereksperimen sains, jika tidak, akan mempersulit anak-anak mengenal sains untuk kehidupan selanjutnya. Anak-anak perlu mendapatkan lebih banyak pengalaman sains.

Jadi, pembelajaran sains pada anak usia dini bertujuan untuk memberikan lebih banyak pengalaman sains kepada anak. Pengalaman sains tersebut akan membantu mengoptimalkan perkembangan $\mathrm{C}_{\mathrm{C}}$ anak $\mathrm{c}$ dan mengembangkan beberapa kemampuan sains seperti mengamati, melakukan percobaan, menyampaikan konsep sains yang diketahui, memiliki sikap-sikap sains dan lain-lain sebagai bekal anak dalam menjalani kehidupan di masa yang datang. Selain itu, sains juga berfungsi sebagai alat untuk mengembangkan lima aspek perkembangan anak usia dini.

Dalam proses pembelajaran sains, pendidik anak usia dini harus mendesain pembelajaran sedemikian rupa agar sesuai dengan tahapan perkembangan dan psikologis anak. Desain pembelajaran harus menekankan pada keaktifan anak. Guru harus lebih kreatif dalam memfasilitasi kebutuhan anak terhadap sains ini agar menjadi suatu kegiatan yang bermanfaat dan menyenangkan bagi anak.

Hasil penelitian yang dilakukan Roza (2012) menyimpulkan bahwa metode pembelajaran sains yang diberikan guru kurang menarik. Faktor penghambat dalam pembelajaran sains yaitu guru masih kurang kreatif dalam merancang kegiatan sains. Hal tersebut menyebabkan anak tidak memiliki pengalaman dalam bereksplorasi, bereksperimen dan melakukan pengamatan sebagai suatu keterampilan proses sains.

Selanjutnya survey yang dilakukan Yulianti (2008) pada 320 guru dari 1.995 Guru Taman Kanak-kanak di Semarang menyatakan bahwa $80 \%$ guru mengalami kendala strategi pembelajaran bermain sains, $80 \%$ mengalami kesulitan dalam sistem penilaian, dan $78 \%$ kesulitan dalam menyusun skenario pembelajaran sains.

Idealnya, apa yang terdapat dalam indikator perkembangan, telah mampu dilewati atau dipahami oleh anak-anak setelah dilakukan proses pembelajaran. Namun, ada beberapa indikator yang dijabarkan terkait perkembangan kemampuan sains, belum dicapai secara optimal oleh anak. Perkembangan kemampuan sains anak belum optimal dalam hal pemahaman konsep sains, yaitu anak belum mengetahui benda-benda mana yang terapung dan tenggelam di air. Ketika anak-anak ditanya tentang benda yang terapung dan tenggelam, anak belum mengetahui dan belum bisa membedakan mana yang tenggelam dan mana yang terapung. Anak-anak masih terlihat bingung saat ditanya. Selain itu, anak tidak mendapatkan pengalaman dalam melakukan keterampilan proses sains seperti melakukan percobaan, mengamati, dan mengklasifikasi.

Dominasi guru dalam proses pembalajaran sains merupakan salah satu faktor yang menyebabkan anak tidak mendapatkan pengalaman belajarnya secara langsung, yang berdampak pada terhambatnya perkembangan kemampuan sains anak, baik terkait kemampuan proses, sikap dan pemahaman konsep sains. Dengan kondisi seperti ini, pembelajaran sains tidak akan bermakna bagi anak dan menjadikan anak cepat bosan.

Agar suatu pembelajaran dapat berjalan dengan optimal sesuai tujuan pembelajaran, diperlukan pemilihan pendekatan pembelajaran yang tepat. Maka, upaya pembaharuan tersebut bisa dilakukan dengan memilih pendekatan pembelajaran yang sesuai dengan karakteristik indikator perkembangan sains, khususnya indikator yang belum dicapai oleh anak.

Berdasarkan indikator yang belum dicapai anak, yaitu mengetahui benda-benda mana yang terapung dan tenggelam di air, mampu melakukan percobaan tenggelam terapung, mampu melakukan kegiatan pengamatan, dan mampu mengklasifikasikan bendabenda yang terapung dan tenggelam di air, maka 
pendekatan yang tepat dengan indikator tersebut adalah pendekatan yang lebih menekankan keaktifan anak dalam membangun sendiri pengetahuannya atau yang bersifat student centered, bukan lagi yang bersifat teacher centered.

Hal tersebut senada dengan yang diungkapkan oleh Harlen \& Qualter (dalam Pereira, 2011: 23) bahwa sains dan teknologi harus ada pada pendidikan anak usia dini dengan pendekatan yang berpusat pada anak dan dengan lingkungan sosial konstruktivistik.

Salah satu pendekatan yang berpusat pada anak adalah pendekatan konstruktivistik. Pendekatan konstruktivistik berpandangan bahwa pengetahuan adalah hasil konstruksi dari individu sendiri. Pembelajaran akan terpusat pada anak, jika anak tersebut aktif membangun pengetahuannya.

Kunci utama konstruktivisme adalah menyusun pengetahuan. Canella, Reiff, Dejong, dan Groomes (dalam Suyanto, 2005: 148) berpendapat bahwa belajar adalah proses membangun pemahaman dengan mengaitkan pengetahuan baru ke dalam struktur pengetahuan yang telah dimiliki sebelumnya. Pendekatan ini berasumsi bahwa saat anak berinteraksi dengan dunia sekitar, anak mengembangkan ide yang kompleks dan bervariasi. Struktur pengetahuan anak berubah karena proses konstruksi. Proses konstruksi terjadi ketika anak menambah dan merevisi struktur pengetahuan lama menjadi struktur pengetahuan baru melalui proses pembelajaran.

Pemilihan pendekatan konstruktivistik dalam pembelajaran sains ini memiliki beberapa alasan, antara lain:

1. Sesuai dengan indikator perkembangan yang ingin di capai, yaitu anak mengetahui benda-benda mana yang terapung dan tenggelam di air, mampu melakukan percobaan tenggelam terapung, mampu melakukan kegiatan pengamatan, dan mampu mengklasifikasikan benda-benda yang terapung dan tenggelam di air.

2. Memfasilitasi sifat rasa ingin tahu anak yang tinggi dengan mengkonstruksi sendiri dari pengalaman belajarnya.

3. Mengembangkan kemampuan berpikir anak, karena proses mengonstruksi pengetahuan tidak lepas dari proses berpikir.

4. Pemahaman terhadap suatu konsep akan lebih mudah, karena pembelajaran berbasis penemuan.

5. Adanya scaffolding yang membantu anak bisa sampai pada kemampuan yang lebih tinggi.

Pendekatan konstruktivistik jika diterapkan untuk anak usia TK bukanlah hal yang rumit. Untuk mencapai tujuan pembelajaran tentang kemampuan anak dalam mengklasifikasikan benda-benda yang terapung di air, misalnya sangatlah mudah. Biarkan anak memainkan perannya sebagai anak aktif yang memiliki rasa ingin tahu yang tinggi, mencoba memasukkan sendiri bendabenda yang ada di sekitarnya ke dalam air, sehingga dengan pengamatannya dan skema-skema yang telah terbentuk di otaknya, anak-anak akan membangun sendiri pengetahuannya tentang benda apa saja yang akan terapung di air.

Prastowo (2012: 209) mengungkapkan bahwa sesuai prinsip konstruktivisme, seseorang akan belajar jika anak aktif mengonstruksi pengetahuan di dalam otaknya. Salah satu cara mengimplementasikannya di kelas adalah dengan mengemas materi pembelajaran dalam bentuk LKS.

Pada pendidikan anak usia dini khususnya di TK, LKS lebih dikenal dengan istilah LKA, yaitu lembar kerja anak. LKA akan membantu proses pembelajaran yang menggunakan pendekatan konstruktivistik, karena anak akan lebih aktif dan mandiri.

Maka, berdasarkan permasalahan yang telah dipaparkan di atas, peneliti mengembangkan Lembar Kerja Anak (LKA) dengan menggunakan pendekatan konstruktivistik untuk mengoptimalkan perkembangan kemampuan sains anak tersebut. LKA sains dengan menggunakan pendekatan konstruktivistik ini dikembangkan agar anak mendapat pengalaman sainsnya secara langsung dengan melakukan percobaan, pengamatan dan kemudian membangun sendiri pengetahuannya sehingga mengetahui dan mampu mengklasifikasikan benda-benda apa saja yang terapung dan tenggelam di air.

Penelitian pengembangan ini bertujuan untuk mengetahui proses pengembangan LKA dengan menggunakan pendekatan konstruktivistik untuk meningkatkan kemampuan sains anak. Mengetahui peningkatan kemampuan sains anak setelah digunakan LKA dengan menggunakan pendekatan konstruktivistik yang dikembangkan.

Penelitian ini juga diharapkan memberikan manfaat dengan tersedianya LKA sains dengan menggunakan pendekatan konstruktivistik untuk anak Taman Kanakkanak yang diharapkan bisa menjadikan pembelajaran sains untuk anak usia dini lebih menyenangkan dan bermakna serta bisa meningkatkan kemampuan sains anak secara maksimal. Selain itu diharapkan bisa memberikan sumbangan dalam konsep pembuatan LKA bagi para praktisi pendidikan, khususnya pendidik anak usia dini. Pengembangan LKA dengan menggunakan pendekatan konstruktivistik juga akan memenuhi kebutuhan anak usia dini sebagai anak yang memiliki rasa ingin tahu yang tinggi.

Adapun kemampuan sains yang dimaksud dalam penelitian ini merupakan kemampuan sains anak yang 
terkait keterampilan proses, yaitu anak mampu melakukan percobaan, pengamatan terhadap benda-benda di sekitar anak dan kemudian mengklasifikasikan bendabenda tersebut dalam kategori benda yang terapung dan tenggelam di air. Pemahaman terhadap konsep sains, yaitu mengetahui benda apa saja yang terapung dan tenggelam di air. Memiliki sikap-sikap sains, sebagaimana disebutkan Nugraha (2008: 97), diantara sikap-sikap sains, yaitu: rasa tanggung jawab, rasa ingin tahu, disiplin, tekun, jujur, dan terbuka terhadap pendapat lain. Namun dalam penelitian ini sikap sains yang diambil adalah sikap bertanggung jawab anak.

\section{METODE PENELITIAN}

\section{Model Pengembangan}

Penelitian ini adalah penelitian pengembangan. Dalam pengembangan ini digunakan model desain yang dikemukakan oleh Willis (dalam Roos, 2012: 3), yaitu model desain Recursive, Reflective, Design and Development yang lebih dikenal dengan singkatan R2D2. Terdapat 3 fokus dalam model pengembangan R2D2, yaitu: (1) define focus (pendefinisian), (2) design and development (perancangan dan pengembangan), serta (3) desimination (penyebarluasan). Adapun desain uji coba atau evaluasi formatif dalam proses pengembangan ini menggunakan model Dick and Carey sebagaimana Willis and Wright (dalam ocedtheories.wikispaces.com) menyebutkan bahwa disarankan dalam tehnik evaluasi formativ menggunakan model Ragan and Smith atau model Dick and Carey.

\section{Desain Uji Coba}

Uji coba yang dilakukan terdiri dari uji ahli, uji perorangan, uji kelompok kecil, dan uji coba lapangan. Draft awal yang telah selesai dikembangkan dilakukan review atau validasi oleh para ahli sebanyak 3 orang ahli, yaitu ahli desain pembelajaran, ahli isi bidang studi, dan ahli media pembelajaran, sebagaimana diungkapkan oleh Suparman (dalam Lestari, 2013: 104) menyebutkan jumlah ahli dalam bidang studi, ahli pengembang instruksional dan ahli produksi media untuk merevisi produk ada sebanyak 1-3 orang.

Selanjutnya uji coba perorangan yang dilakukan pada anak TK sebanyak 3 orang dengan teknik wawancara. Hasil uji coba ini akan menjadi acuan untuk melakukan revisi pada draft II dan selanjutnya menghasilkan draft III. Draft III diuji cobakan pada kelompok kecil, yaitu anak TK sebanyak 8 orang. Uji coba dengan menggunakan teknik wawancara kepada anak, dan hasil uji coba ini akan dijadikan panduan untuk merevisi draft III menjadi draft akhir. Setelah menjdi draft ahkir, produk diuji pada uji coba lapangan. Uji coba dilakukan dengan menggunakan desain eksperimen one shot case study. Hasil dari uji coba lapangan untuk mengetahui pengaruh LKA yang dikembangkan dengan pendekatan konstruktivistik terhadap kemampuan sains anak.

\section{Subjek Uji Coba}

Subjek uji coba dalam penelitian ini adalah anak Taman Kanak-Kanak kelompok B yang berjumlah 24 anak.

\section{Jenis Data}

Data yang digunakan adalah data kualitatif dan data kuantitatif. Data kualitatif merupakan data yang dinyatakan dalam bentuk kata-kata atau simbol yang akan dideskripsikan. Data kualitatif adalah data yang diperoleh dari uji validasi ahli, jawaban wawancara dari anak pada uji coba perorangan dan kelompok kecil. Sedangkan data kuantitatif merupakan data-data yang berbentuk angka yang diolah dengan rumus statistik, yaitu data hasil uji coba lapangan setelah penggunaan LKA yang dikembangkan.

\section{Instrumen Pengumpulan Data}

Adapun instrumen yang digunakan untuk mengumpulkan data adalah: (1) Angket yang digunakan untuk mengumpulkan data dari uji coba ahli, yaitu ahli media, ahli desain pembelajaran dan ahli materi. Angket yang dibuat menggunakan skala Guttman sebagaimana disebutkan Sugiyono (2011: 96), bahwa skala pengukuran dengan tipe ini akan didapat jawaban yang tegas, yaitu "ya-tidak"; "benarsalah"; "pernah-tidak pernah" dan lain-lain. Sehingga untuk keperluan revisi akan didapat jawaban yang tegas, "revisi-tidak revisi". (2) Panduan wawancara yang digunakan untuk mengumpulkan data dari anak TK saat uji perorangan dan kelompok kecil. Panduan yang dibuat didasarkan pada indikator tentang kemenarikan LKA yang dikembangkan untuk mengetahui respon anak untuk keperluan perbaikan. Selain untuk keperluan perbaikan, instrumen dalam bentuk panduan wawancara juga digunakan pada uji coba lapangan untuk mengetahui kemampuan sains anak setelah menggunakan LKA tersebut. (3) Lembar observasi yang digunakan untuk mengumpulkan data pada saat uji coba lapangan yang terkait dengan keterampilan proses sains anak, yaitu mengamati, mengklasifikasi, dan sikap bertanggung jawab.

\section{Teknik Analisis data}

Data dari hasil uji ahli atau pengamatan validator dianalisis dengan teknik deskriptif yaitu mendiskripsikan kata-kata atau simbol yang didapat tersebut menjadi sebuah kesimpulan.

Data dari uji coba perorangan dan kelompok kecil digunakan teknik statistik deskriptif. Dari hasil 
wawancara yang diperoleh, data tiap indikator pada instrumen dihitung dengan persentase jumlah anak yang menjawab "ya", dengan rumus berikut:

$$
\mathrm{P}=\underline{\mathrm{F}} \times 100
$$

$P=$ persentase jawaban "ya:

$\mathrm{F}=$ frekuensi jawaban "ya"

$\mathrm{N}=$ jumlah responden/ anak

Hasil persentase selanjutnya dikonversi ke dalam tabel klasifikasi kelayakan produk berikut untuk mengambil keputusan revisi atau tidak revisi.

Tabel 1. Klasifikasi kelayakan produk

\begin{tabular}{|c|c|c|}
\hline $80-100 \%$ & Sangat baik & Tidak revisi \\
\hline $66-79 \%$ & Baik & \\
\hline $56-65 \%$ & Cukup & \multirow{2}{*}{ Revisi } \\
\hline $40-55 \%$ & Kurang baik & \\
\hline $0-39 \%$ & Tidak baik & \\
\hline
\end{tabular}

Sumber: Sugiyono (dalam Laila, 2012: 55)

a. Data dari uji coba lapangan terhadap LKA yang dikembangkan menggunakan desain eksperimen pada bentuk Pre Experimental Design tipe one shot case study. Pre Experimental Design dipilih karena tidak memungkinkan bagi peneliti untuk melakukan eksperimen yang sesungguhnya dengan mengontrol banyaknya variabel luar yang mempengaruhi jalannya eksperimen pada anak-anak TK yang tingkah dan karakternya sulit untuk dibatasi dan dimanipulasi.

Sedangkan tipe one shot case study dipilih karena pada penelitian ini tidak memungkinkan bagi peneliti untuk melaksanakan pretest, karena ada beberapa indikator yang tidak bisa dilakukan pretest. Jadi, peneliti hanya melakukan posttest kepada subjek uji coba ketika dilaksanakan perlakuan untuk mengetahui kemampuan sains anak, yaitu sikap tanggungjawab, kegiatan mengamati, mengklasifikasi melalui penggunaan LKA yang dikembangkan. Adapun pola desain one shot case study tersebut adalah:

\section{X $\quad \mathrm{O}$}

Gambar 1. Desain Eksperimen one shot case study (Arikunto, 2010: 124)

$\mathrm{X}$ adalah treatment atau perlakuan. $\mathrm{O}$ adalah hasil observasi sesudah treatment. Menurut Arikunto (2010: 124), dari hasil posttest tersebut diambil kesimpulan dengan 2 cara, dalam hal ini peneliti memilih cara pertama yaitu melihat rata-rata hasil dan membandingkan dengan standar yang diinginkan. Rumus untuk mencari rata-ratanya adalah sebagai berikut (Murdan, 2006: 47):

$$
\mathrm{M}=\frac{\sum \mathrm{x}}{\mathrm{N}}
$$

$\mathrm{M}=$ mean yang dicari

$\sum \mathrm{x}=$ jumlah keseluruhan bintang

$\mathrm{N}=$ jumlah anak

\section{HASIL DAN PEMBAHASAN}

Pada hasil validasi dari ahli bidang studi sains anak usia dini, validator menganggap isi LKA sudah sesuai dengan indikator pembelajaran sains dan tidak perlu direvisi, karena untuk pembelajaran sains, diperlukan adanya praktek langsung yang sudah tercantum pada LKA bagian 2, sebagaimana diungkapkan oleh Conant (dalam Samatowa, 2011: 1) yang mendefinisikan sains sebagai suatu deretan konsep serta skema konseptual yang berhubungan satu sama lain, dan yang tumbuh sebagai hasil eksperimentasi dan observasi. Sesuai dengan materinya adalah benda-benda yang terapung dan tenggelam, maka anak-anak akan melakukan eksperimen dan kemudian mengamatinya. Sebagaimana Johnston (2005) mengungkapkan, observation is one of the most important skills for both the scientist and in the early years. Keterampilan proses sains selain melakukan percobaan dan mengamati adalah menuliskan hasil. Untuk menuliskan hasil percobaan, sudah disediakan lembar untuk menuliskan hasil percobaan yang terdapat pada bagian $3 \mathrm{~A}$, karena anak-anak belum mampu menulis sendiri dari hasil percobaannya dan terkendala waktu jika anak-anak harus mengkomunikasikan secara lisan satu persatu hasil percobaan anak, maka pengembang membuatnya dalam bentuk gambar, sehingga anak hanya perlu memberikan tanda centrang sesuai hasil percobaan.

Hal yang perlu direvisi menurut validator adalah terkait gambar, ilustrasi, penggunaan kalimat, dan bendabenda yang dimuat di LKA. Berdasarkan kemampuan anak yang masih terbatas, maka gambar tokoh anak yang ada di cover harus disesuaikan dengan gambar tokoh yang ada dalam LKA. Hal ini agar memudahkan anak mengidentifikasi tokoh dalam LKA. Ilustrasi background pada cover juga harus disesuaikan untuk mempermudah anak memahami maksud ilustrasi. Background tempat anak belajar adalah di TK daerah perkotaan, yang kontekstual dengan anak, bukan di pegunungan sebagaimana draft awal yang dibuat oleh pengembang. Penggunaan kalimat di LKA juga terlalu panjang. Pada bagian mengklasifikasi, menurut validator, jangan hanya 
mencantumkan benda yang sesuai dengan percobaan, tapi hendaknya menambahkan benda lain agar mengoptimalkan kemampuan anak, tidak hanya pada tahap recalling saja.

Pada hasil validasi ahli desain pembelajaran konstruktivistik, validator menganggap LKA yang dikembangkan sudah sesuai dengan pendekatan konstruktivistik. LKA membantu anak mengkonstruksi sendiri pengetahuannya, dari kegiatan mencermati gambar pada bagian 1 dan dilanjutkan dengan kegiatan percobaan pada bagian 2, anak akan mengkonstruksi pengetahuannya. Melalui LKA ini anak akan berinteraksi dengan beragam sumber seperti yang diungkapkan oleh Parkay (dalam Mustaji, 2009: 34) bahwa dalam pembelajaran yang konstruktivistik, siswa aktif mengkonstruksi pengetahuan mereka sendiri. Mereka berinteraksi dengan beragam sumber belajar, kemudian menentukan apa yang akan pelajari anak.

LKA yang dikembangkan bersifat top-down (atasbawah) sebagaimana Slavin (2009: 8) mengutarakan beberapa hal yang terkait pembelajaran konstruktivistik antara lain pengolahan atas-bawah. Istilah atas bawah berarti bahwa anak mulai dengan persoalan yang rumit untuk diselesaikan dan kemudian mengembangkan atau menemukan (dengan panduan guru) kemampuan dasar yang diperlukan. Dalam hal ini, LKA diawali dengan cerita seorang anak yang kehilangan pasta giginya. Persoalan ini menuntun anak untuk ikut memecahkan masalah anak tersebut dengan melakukan percobaan.

LKA berpusat pada anak. Menurut Prastowo (2012: 205) Pengembangan LKA memiliki fungsi sebagai bahan ajar yang bisa meminimalkan peran pendidik, namun lebih mengaktifkan anak. Oleh sebab itu pada bagian 1, 2, dan 3, kegiatan yang dirancang adalah yang bersifat mengaktifkan anak, dan guru hanya sebagai fasilitator, mulai dari kegiatan mencermati gambar, melakukan percobaan, sampai kegiatan menuliskan hasil dan mengklasifikasi.

LKA menstimulasi anak untuk aktif berinisiatif sendiri. Dengan adanya LKA ini, anak bisa berinisiatif untuk melakukan percobaan karena sudah terdapat petunjuk untuk melakukan percobaan, setelah itu telah tersedia juga lembar untuk menuliskan hasilnya dan mengklasifikasikan benda-benda yang terapung dan tenggelam.

LKA berbasis pembelajaran penemuan. Sebagaimana ciri khas dari pembelajaran konstruktivistik yang dikemukakan oleh Slavin (2009: 8) adalah pembelajaran berbasis penemuan. Dalam LKA telah dimuat petunjuk percobaan untuk anak-anak, sehingga anak bisa melakukan penemuan tentang benda apa saja yang terapung dan tenggelam di air.

Selain itu, ciri pembelajaran konstruktivistik lain yang dikemukakan oleh Slavin (2009: 8) adalah adanya scaffolding. LKA yang dikembangkan telah berpeluang menerapkan scaffolding. Pada bagian 1, guru bisa menjadi scaffolder dengan membiarkan dulu anak untuk mengamati cerita dan kemudian membantu anak memahaminya.

Validator juga memberikan masukan/ saran di kolom saran, yaitu: "perhatikan penulisan ejaan: tau $=$ tahu, yuk= ayo. Karena LKA yang dikembangkan ini menggunakan pendekatan konstruktivistik, maka dari segi penulisan ejaan harus ditulis dengan ejaan yang baku. Hal ini bertujuan agar anak sejak dini telah mengetahui bahasabahasa yang baku secara tidak langsung.

Pada hasil validasi ahli media pembelajaran, validator menganggap ukuran dan jenis font yang digunakan dalam LKA sudah sesuai untuk sasaran pengguna yaitu anak TK kelompok B. Namun untuk gambar dan ilustrasi dianggap monoton karena ukurannya selalu sama, padahal fokus pembahasan berbeda.

Levio dan Lentz (dalam Arsyad, 2007: 17) menjelaskan bahwa dari temuan penelitian yang mengungkapkan bahwa lambang visual atau gambar memperlancar tujuan memahami dan mengingat informasi dan pesan yang terkandung dalam gambar. Maka penting sekali untuk membuat gambar yang tidak monoton dalam LKA, apalagi untuk anak usia TK. Seperti saran validator, agar pesan dalam gambar bisa tersampaikan, gambar dan ilustrasi pada draft awal direvisi menjadi gambar dan ukuran yang berbeda sesuai fokus pembahasannya.

Setelah pengembang melakukan revisi dari masukan semua validator, selanjutnya semua validator sudah menganggap bahwa LKA dengan menggunakan pendekatan konstruktivistik yang dikembangkan sudah layak dan bisa digunakan ke lapangan pada target pengguna adalah anak-anak kelompok $\mathrm{B}$.

Hasil uji coba memperlihatkan bahwa anak belum mampu mengikuti petunjuk berupa tanda panah yang disambung ke halaman berikutnya. Ternyata anak mengacuhkan tanda panah tersebut, anak tetap membaca gambar dengan cara menyelesaikannya terlebih dahulu 1 halaman baru ke halaman berikutnya. Dari temuan ini, pengembang mengubah instruksi dengan mengikuti kemampuan anak, yaitu tidak membuat panah yang menyambung ke halaman berikutnya, tapi menyelesaikan dahulu pada satu halaman.

Pada hasil uji kelompok kecil pada 8 anak, didapatkan hasil adanya 1 indikator yang perlu dilakukan revisi, karena hanya memperoleh porsentase sebesar $25 \%$, yaitu pada gambar kelereng. 4 orang anak mengungkapkan bahwa gambar kelereng tersebut tidak jelas, karena lebih menyerupai gambar bola. Sehingga gambar perlu direvisi semirip mungkin dengan kelereng. Sedangkan beberapa indikator lain yang tidak mencapai $100 \%$ tidak perlu direvisi dan tetap berada pada kualifikasi sangat baik, yaitu masing-masing sebesar $87,5 \%$.

Hasil penelitian dari uji coba lapangan memperlihatkan bahwa dengan penerapan LKA yang konstruktivistik dapat membantu anak membangun sendiri pengetahuannya tentang sains dan terampil dalam 
melakukan proses-proses sains seperti melakukan percobaan, mengamati, menuliskan hasil, dan mengklasifikasikan benda-benda yang terapung dan tenggelam di air.

Hal itu terlihat dari hasil observasi setelah dilakukan pembelajaran yang menerapkan LKA dengan menggunakan pendekatan konstruktivistik sebagai berikut: (1) Pada aspek keterampilan mengamati, 21 anak memperoleh 3 bintang, anak mau melakukan kegiatan mengamati secara keseluruhan dengan aktif, hanya 3 anak yang memperoleh 2 bintang, anak mau mengamati tapi hanya sebagian saja. (2) Pada aspek keterampilan mengklasifikasi, semua anak memperoleh 3 bintang, semua anak mau melakukan kegiatan mengklasifikasi secara keseluruhan dengan aktif. (3) Pada aspek sikap tanggungjawab, 19 anak memperoleh 3 bintang, mau mengembalikan peralatan yang telah digunakan tanpa diminta oleh guru, hanya 5 anak yang memperoleh 2 bintang, mau mengembalikan peralatan yang telah digunakan tapi setelah diminta oleh guru. (4) Pada aspek pemahaman konsep (hasil), semua anak mendapatkan 3 bintang, semua anak mengetahui benda yang terapung dan tenggelam lebih dari 8 benda.

Hal ini menunjukkan bahwa LKA dengan menggunakan pendekatan konstruktivistik yang digunakan berpengaruh terhadap kemampuan sains anak kelompok B. Sebagaimana Pendekatan konstruktivistik berpandangan bahwa pengetahuan adalah hasil konstruksi dari individu sendiri. Pembelajaran akan terpusat pada anak, jika anak tersebut aktif membangun pengetahuannya.

\section{PENUTUP}

\section{Simpulan}

Dihasilkan sebuah produk berupa LKA dengan menggunakan pendekatan konstruktivistik yang dikembangkan berdasarkan model R2D2 yang memiliki tiga fokus kegiatan pengembangan, diantaranya define focus, design and development focus, dan desimination focus. Pengembangan produk ini telah melewati tiga tahap uji coba, yaitu uji ahli, uji coba perorangan, dan uji coba kelompok kecil yang bertujuan untuk perbaikan produk.

1. Pada uji ahli materi terdapat beberapa kekurangan sehingga dilakukan revisi, yakni menambahkan satu gambar anak yang tidak tercantum di cover sesuai dengan gambar anak dalam isi LKA, mengubah ilustrasi background cover menjadi ilustrasi yang sesuai lingkungan TK, meminimalkan penggunaan kalimat pada isi LKA, menambahkan benda lain (kelereng, kunci, uang logam, piring plastik, dan gelas plastik) pada bagian mengklasifikasi, mengganti ember menjadi toples bening, dan menambahkan satu kalimat sebagai instruksi cara mengerjakan bagian $3 \mathrm{~B}$.

2. Pada uji ahli desain pembelajaran secara keseluruhan sudah dianggap sesuai dengan pembelajaran konstruktivistik oleh validator, hanya ada tambahan saran, yakni sebaiknya menggunakan kata-kata yang baku dalam LKA seperti "yuk", dan "tau" diganti menjadi "ayo", dan "tahu.

3. Pada uji ahli media pembelajaran terdapat beberapa kekurangan yang perlu direvisi, yakni mengubah ukuran tiap gambar sesuai dengan fokus yang ingin disampaikan agar lebih fokus dan tidak monoton, membuat gambar dan ilustrasi yang berfokus pada hal atau benda yang ingin dijelaskan agar pesan yang ingin disampaikan bisa sampai kepada anak.

4. Pada uji coba perorangan yang dilakukan pada 3 anak, ada 2 poin yang tidak mencapai persentase $100 \%$, yaitu sebesar $33 \%$ dan $0 \%$. Maka poin tersebut harus dilakukan revisi karena berada pada kualifikasi tidak baik, yaitu mengganti urutan gambar pada bagian 2, dan mengganti gambar gelas plastik menjadi gambar bola agar bisa terlihat dengan jelas.

5. Pada uji coba kelompok kecil yang dilakukan pada 8 anak, ada 5 poin yang tidak mencapai $100 \%$, yakni 4 poin sebesar $87,5 \%$ dan 1 poin sebesar $25 \%$. Maka yang dilakukan revisi adalah yang persentasenya $25 \%$ karena berada pada kualifikasi tidak baik dan harus direvisi, yaitu memperjelas gambar kelereng.

6. LKA dengan menggunakan pendekatan konstruktivistik yang dikembangkan dapat meningkatkan kemampuan sains anak kelompok B berdasarkan hasil perolehan bintang anak setelah dilakukan perlakuan dengan menggunakan produk yang dikembangkan:

a. Pada keterampilan mengamati, hanya 3 anak yang mendapat bintang 2 dengan capaian anak mau mengamati tapi hanya sebagian saja, selebihnya mendapat bintang 3, mau melakukan kegiatan mengamati secara keseluruhan dengan aktif dengan rata-rata perolehan skornya adalah 95,75 yang berarti telah melebihi standar yang diinginkan.

b. Pada ketrampilan mengklasifikasi semua anak mendapatkan bintang 3, semua anak mau melakukan kegiatan mengklasifikasi secara keseluruhan dengan aktif yang berarti telah melebihi standar yang diinginkan.

c. Pada sikap tanggungjawab, hanya 5 anak yang mendapat bintang 2 dengan capaian mau mengembalikan peralatan yang telah digunakan tapi setelah diminta oleh guru, selebihnya 
mendapat bintang 3 , mau mengembalikan peralatan yang telah digunakan tanpa diminta oleh guru dengan rata-rata perolehan skornya adalah 92,91 yang berarti telah melebihi standar yang diinginkan.

d. Pada aspek hasil atau pemahaman konsep, semua anak mengetahui benda yang terapung dan tenggelam lebih dari 8 benda dan semuanya mendapatkan bintang 3 yang berarti telah melebihi standar yang diinginkan.

\section{Saran}

Saran yang diberikan dari hasil penelitian pengembangan ini akan dipaparkan dalam tiga kategori, yaitu: saran pemanfaatan, saran desiminasi produk, dan saran kelanjutan pengembangan.

1. Saran Pemanfaatan Produk

Saran pemanfaatan produk ini adalah sebagai berikut:

a. Produk LKA dengan menggunakan pendekatan konstruktivistik ini adalah produk pembelajaran dalam bentuk bahan ajar cetak yang dikembangkan untuk digunakan oleh anak-anak TK kelompok B saat kegiatan pembelajaran pada tema air dengan subtema benda-benda yang terapung dan tenggelam di air.

b. Produk LKA ini dikembangkan dengan menggunakan pendekatan konstruktivistik, sehingga guru sangat disarankan agar menjalankan peran sebagai fasilitator dalam mendampingi anak-anak saat proses pembelajaran.

2. Saran Desiminasi Produk

LKA dengan menggunakan pendekatan konstruktivistik diharapkan bisa disebarluaskan dan digunakan pada TK yang memiliki karakteristik yang sama dengan TK Sartika Surabaya, karena pengembangan LKA ini dilakukan secara kontekstual dan berkaitan langsung dengan calon pengguna sebagai subjek uji coba dalam memperoleh tanggapan yang konstruktif. Sehingga LKA ini bisa digunakan pada TK-TK yang serumpun dengan TK Sartika Surabaya.

3. Saran Kelanjutan Pengembangan

LKA dengan menggunakan pendekatan konstruktivistik yang dikembangkan talah mampu meningkatkan kemampuan sains anak kelompok B TK Sartika Surabaya, maka disarankan bagi peneliti lain untuk mengembangkan LKA serupa pada tema atau subtema yang berbeda.

Bagi pihak-pihak yang ingin mengembangkan LKA lebih lanjut pada materi lain disarankan agar dapat menyesuaikan dengan karakteristik pebelajar, terutama jika penggunanya adalah anak TK, disarankan untuk memperhatikan dalam hal pembuatan gambar, ilustrasi, panjang pendeknya tulisan, dan hal-hal lainnya, sehingga LKA dapat digunakan dengan maksimal.

\section{DAFTAR PUSTAKA}

Arikunto, S. (2010). Prosedur penelitian suatu pendekatan praktik. Bandung: Rineka Cipta

Arsyad, Azhar. (2010). Media pembelajaran. Bandung: Rajawali Pers

Dick, W., Carey, L., and Carey, James O. (2001). The systematic design of instruction. USA: Longman

Lestari, Ika. (2013). Pengembangan bahan ajar berbasis kompetensi. Padang: PT. Indeks

Murdan. (2006). Statistik pendidikan dan aplikasinya. Banjarmasin: Cyprus

Mustaji. Teori, model, dan penelitian pengembangan dalam perspektif teknologi pembelajaran diunduh dari http://pasca.tp.ac.id/site/desain -pembelajarandengan-model-r2d2, pada tanggal 9 Oktober 2013

Nugraha, Ali. (2005). Pengembangan pembelajaran sains pada anak usia dini. Bandung: Jilsi Fondation

Ocedtheories.wikispaces.com. Comparing instructional systems design (ISD) and constructivist approaches. Diunduh dari ocedtheories.wikispaces.com pada 20 Juni 2014

Pereira, Sara J., Rodrigues, M.J., Martins, I.P., and Vieira, R.M.. (2011). "Pre-school science education in Portugal: teacher education and innovative practices". The journal of emergent science. Vo.. 1 No.23, pp. 23-31.

Prastowo, Andi. (2012). Panduan kreatif membuat bahan ajar demokratis. Jogjakarta: Diva Press

Roos, Teunis. (2012). The R2D2 model of instructional design. Diunduh dari

http://etec.ctlt.ubc.ca/510wiki/The_R2D2_Model_of_Inst ructional_Design pada tanggal 19 Desember 2013

Roza, Mela Murti. (2012). "Pelaksanaan pembelajaran sains anak TK Aisyiyah Bustanul Athfal 29 Padang". Pesona PAUD Jurnal Ilmiah PG PAUD. Vol. 1 No. 1. Diunduh dari http://ejournal.unp.ac.id/index.php/paud pada tanggal 9 Oktober 2013

Slavin, Robert E. (2009). Psikologi pendidikan teori dan praktek jilid 1. Jakarta: PT. Indeks Sugiyono. (2011). Metode penelitian kuantitatif, kualitatif dan $R \& D$. Bandung: Alfabeta

Suyanto, S. (2005). Dasar-dasar pendidikan anak usia dini. Yogyakarta: Hikayat Publishing 
Trundle, K.C. (2005). Teaching science during the early childhood years. Diunduh dari Hampton-Brown. NGSP.com pada tanggal 18 Desember 2013

Yulianti, Dwi. (2010). Bermain sambil belajar sains di taman kanak-kanak. Jakarta: PT. Indeks

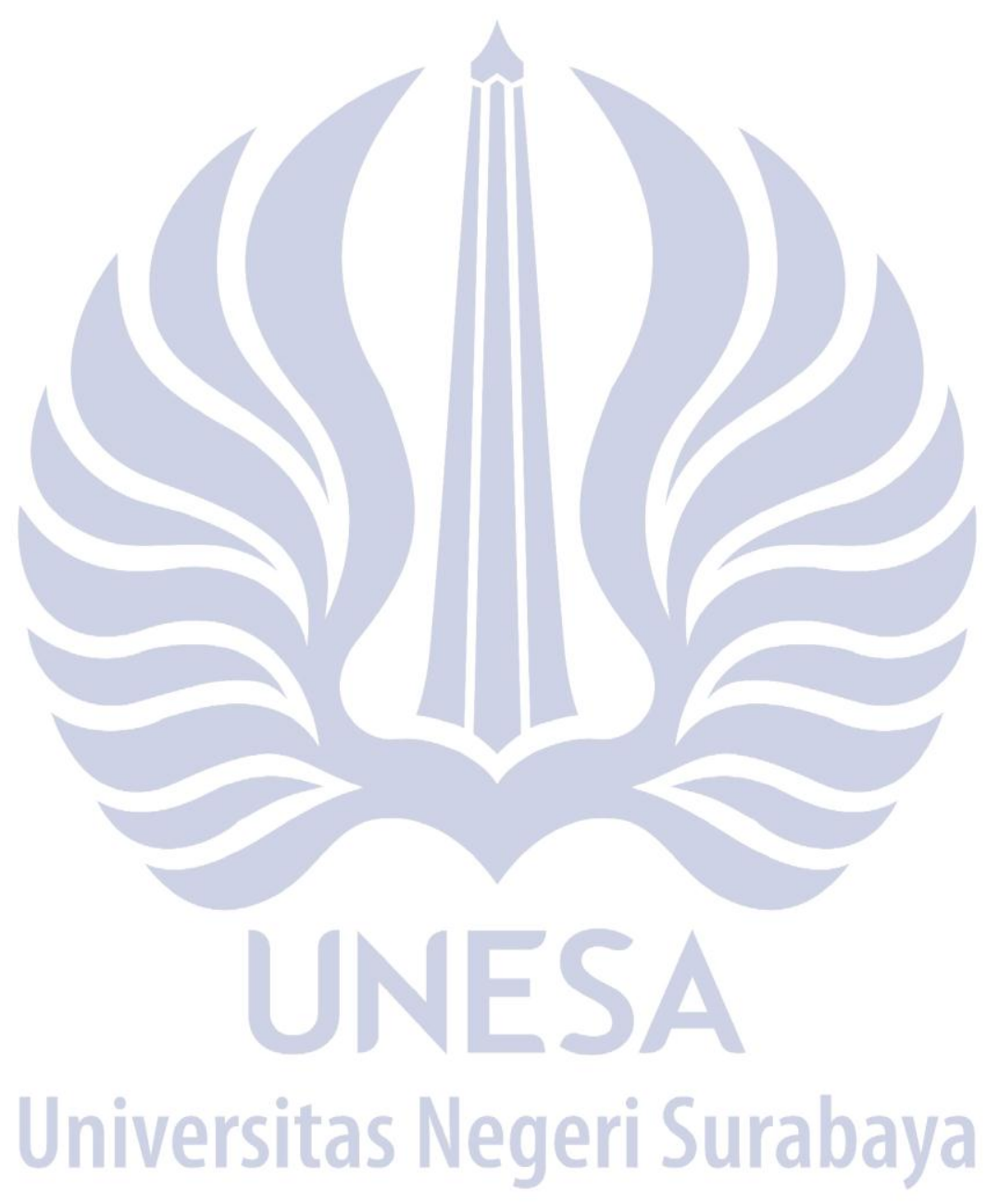

